\title{
Sensor with Intact or Modified Yeast Cells as Rapid Device for Toxicological Test of Chemicals
}

\author{
Roberto Dragone $^{1 *}$, Chiara Frazzoli², Gerardo Grasso ${ }^{3}$, Gloria Rossi ${ }^{1}$ \\ ${ }^{1}$ Institute of Nanostructured Materials, Consiglio Nazionale delle Ricerche, Rome, Italy \\ ${ }^{2}$ Department of Veterinary Public Health and Food Safety, Istituto Superiore di Sanità, Rome, Italy \\ ${ }^{3}$ Department of Agricultural, Environmental and Food Sciences, University of Molise, Campobasso, Italy \\ Email: roberto.dragone@uniroma1.it
}

Received February 2014

\begin{abstract}
Aerobic catabolism of $S$. cerevisiae (cell respiration) is a rapid, cost-effective, and reproducible toxicological endpoint of the whole cells biosensor. To increase the signal intensity, a protocol for the immobilization and modification of the yeast cells is described. In particular, the enzymatic treatment of the immobilized yeast cells allows removing the cell wall and obtaining structurally modified cells namely spheroplasts. Both immobilization and exposure of sensitive cells like spheroplasts confirmed to improve the method's sensitivity vs. the chemicals. The present paper reports the test of different chemicals (including Mercury and wood preservative like Tanalith) present in consumer products, performed both by sensor with intact and modified whole cells.
\end{abstract}

\section{Keywords}

Screening Methods; Spheroplast; Whole Cell; Tanalith; Mercury

\section{Introduction}

Since 1990s biosensors have been studied and developed to test and screen inorganic and organic substances [1-3]. A biosensor consists of 1) a biological recognition element, namely the biomediator, and 2) a transduction element, namely the sensor. Among the wide range of biosensors, those whole cells-based have the advantage of exposing a live entity: this implies the test of multiple possible functional targets simultaneously [4]. For instance, regular aerobic respiration is indicator of normal metabolism of glucose (involving more than 20 enzymes) and mitochondrial functions. The whole cells biosensor based on cellular respiration offers rapid and reproducible measures while allowing useful toxicity ranking of chemicals: in fact, the semiquantitative result is expressed as toxicity index [4].

A key step in the improvement of the whole cells biosensor based on respiration as functional toxicological endpoint has been the immobilization of the biomediator. In fact, the use of suspended cells implies the addition

\footnotetext{
${ }^{*}$ Corresponding author.
}

How to cite this paper: Dragone, R., et al. (2014) Sensor with Intact or Modified Yeast Cells as Rapid Device for Toxicological Test of Chemicals. Journal of Agricultural Chemistry and Environment, 3, 35-40. 
of the cellular suspension to the sample and therefore a sample dilution that, in some cases and depending on method's LoD, may impair the measurement. The method's improvement in sensitivity by immobilization of cells has been detailed and applied in our previous studies, either with yeast (Saccharomyces cerevisiae) and human cells (U-937 cell line) [1,5]. The application on human cells confirmed respiration as robust endpoint to investigate effects on different metabolisms, whereas yeast is particularly interesting for its low cost, rapid reaction and easy handling. In general, yeast is recognized as model organism and is widely used in genetics and molecular biology also for its short generation time (doubling time of ca. $90-140 \mathrm{~min}$ at $30^{\circ} \mathrm{C}$ depending on media).

A further step in the improvement of method's sensitivity involves the partial enzymatic removal of cell wall and therefore the exposure of a more vulnerable entity, namely the spheroplast [6]. In fact, the cell wall (that is a 70 - $100 \mathrm{~nm}$ thick layered structure in S. cerevisiae) may act as chemical-physical shield against chemical stressors and/or affect the cellular uptake of chemicals (due e.g. to surface adsorption and chelation). The present paper describes the protocol and findings of this improvement.

\section{Materials and Methods}

\subsection{Materials}

The yeast cells used are of Saccharomyces cerevisiae Type II (Sigma-Aldrich, USA), Agar microbiology tested and powdered (Sigma-Aldrich, USA). The composition of the biological medium was as follows: yeast extracts for microbiology (Merck, Germany), 0.17\% Universal Peptone M66, 0.17\%, D-Glucose monohydrate, 0.30\%, containing agar, $1 \%$.

Chemical used in consumer products like herbicides, insecticides, pesticide, antiseptics, detergents, disinfectants, and surfactants were tested and in particular: mercury nitrate $0.005 \mathrm{~mol} / \mathrm{L}(0.01 \mathrm{~N})$ (Sigma Aldrich); sodium dodecyl sulphate, SDS (Fluka, Germany). 4-chlorophenol (4-CP) $\geq 99 \%$ (Sigma Aldrich), and a number of wood preservatives, as alkaline copper quaternary, ACQ (Hangzhou Lin'an Tianhong Bio-tech Co. Ltd, China), copper azole (Lonza Wood Protection, Holland), formulation containing copper chelate Cu-N-cyclohexyldiazenium dioxide and Wolmanit $\mathrm{CX}-10$ (copper chelate $\mathrm{Cu}-\mathrm{N}$-cyclohexyldiazenium dioxide wood preservative) (BASF Wolman GmbH, Germany) were tested along with inorganic formulations (chromated copper arsenate, or CCA also known as Tanalith C) and Tanalith E (copper azole wood preservative) (Lonza Wood Protection, Holland). All standards solutions were prepared through dilution with high purity deionized water by Milli- ${ }^{\circledR}$ Integral Water Purification Systems (Merck Millipore, USA).

The protocol requires the following reagents: D-sorbitol, sodium sulfite and formaldehyde solution 37\% (Fluka, Germany), sodium azide purum p.a. $\geq 99.0 \%$, ethanol $\sim 96 \%$, zymolyase-20T (AMS Biotechnology (Europe) Ltd, Switzerland).

To measure and record dissolved $\mathrm{O}_{2}$ consumption rates, Orion ${ }^{\circledR}$ model 97-08 amperometric $\mathrm{O}_{2}$ gas diffusion sensors (MG Scientific, USA), potentiometer GPL 22 (Crison, Italy) and Amel analogical recorder mod. 868 (Amel, Italy) were used. The biosensor was assembled by coupling the oximeter as signal transducer to an agar disk of immobilized yeast cells. The current signal (due to reduction of $\mathrm{O}_{2}$ at the cathode) is expressed in $\mathrm{ppmO}_{2}$. An agar disk of $10 \mathrm{~mm}$ of diameter and a thickness of $1 \mathrm{~mm}$ contains the immobilized cells and is anchored to the gas-permeable membrane on the electrode tip. Both agar disks preparation and biosensor assembly followed the procedure already detailed [1]. To avoid cell contamination, the external surface of the sensor, including the gas-permeable membrane, is cleaned with ethanol $70 \% \mathrm{v} / \mathrm{v}$ solution [7].

\subsection{Methods}

\subsubsection{Respirometric Test}

As already described in literature [5], the interactions of the chemical with mitochondrial membranes can cause a change of the cellular respiration. This change is measured in terms of variation of dissolved $\mathrm{O}_{2}$ concentration, consumption during the aerobic catabolism of an opportune nutrient. The concentration $\mathrm{O}_{2}$ measured is what remains after diffusion across the thickness of the agar gel containing the immobilized cells, from the solution up to sensor's tip. The difference between the $\mathrm{O}_{2}$ concentration in the solution and the $\mathrm{O}_{2}$ measured by the sensor is the $\mathrm{O}_{2}$ consumed during cellular respiration. A typical kinetic curve $\left(\mathrm{ppmO}_{2}\right.$ vs time) of cellular respiration recorded during the test is reported in Figure 1. Measurements are performed in an open system at room temperature 


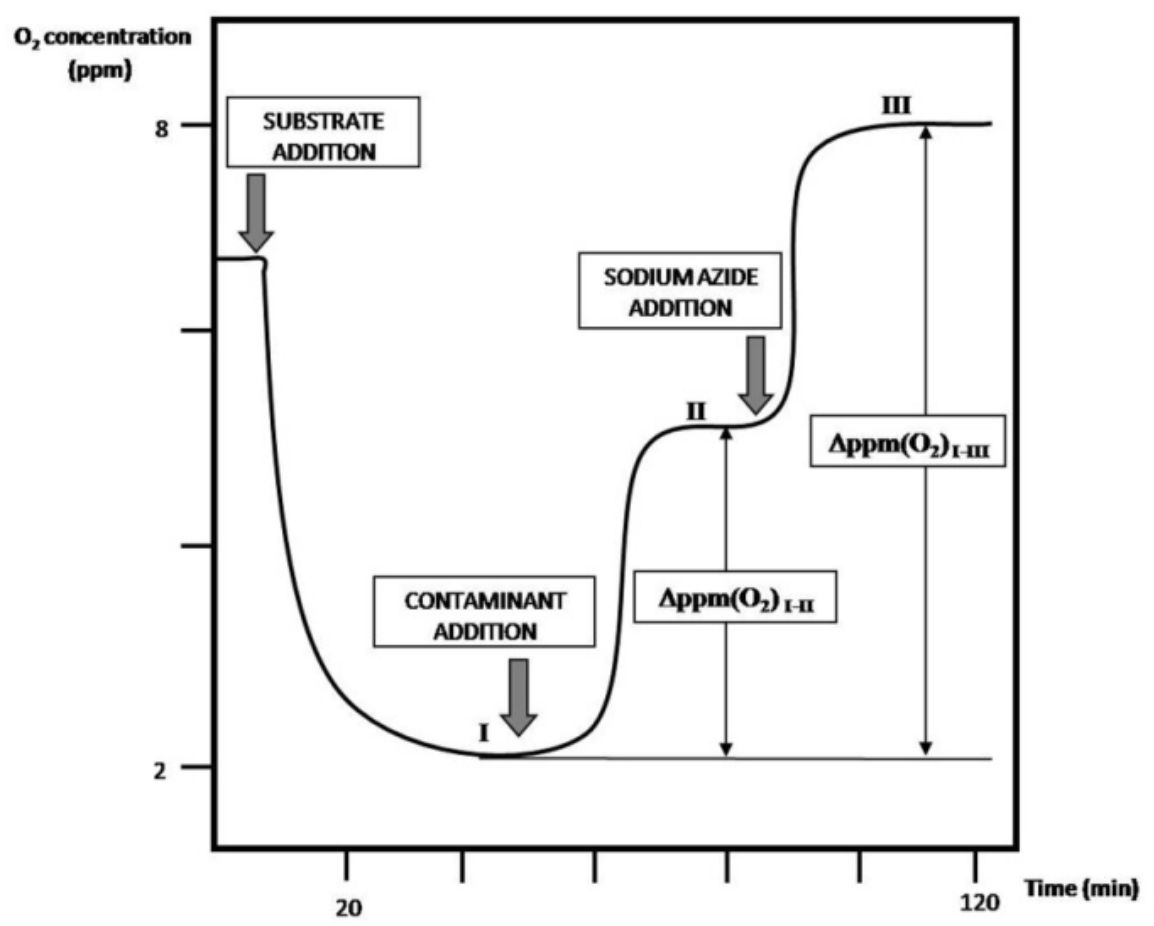

Figure 1. Typical experimental respirometric kinetic curve: analytical parameters are $\Delta \mathrm{ppm}$ $\left(\mathrm{O}_{2}\right)_{\text {I-II }}$ and $\Delta \mathrm{ppm}\left(\mathrm{O}_{2}\right)_{\text {I-IIII }}$, where $\Delta \mathrm{ppm}\left(\mathrm{O}_{2}\right)_{\text {I-II }}$ is the variation of $\mathrm{O}_{2}$ consumption between steady-state $\mathrm{I}$ and $\mathrm{II}$ and $\Delta$ ppm $\left(\mathrm{O}_{2}\right)_{\mathrm{I}-\mathrm{III}}$ is the variation of $\mathrm{O}_{2}$ consumption between steadystate I and III.

$\left(25.0^{\circ} \mathrm{C} \pm 0.1^{\circ} \mathrm{C}\right.$ ), and the dissolved $\mathrm{O}_{2}$ remains constant in the solution (no significant variation of $\mathrm{PO}_{2}$ atmospheric during the time test).

Sensor calibration is performed daily by measuring $\mathrm{O}_{2}$ in open air $\left(\sim 21 \% \mathrm{v} / \mathrm{v}\right.$; the values of $\mathrm{ppmO}_{2}$ in water are reported in an apposite table in function of $\mathrm{P}$ and $\mathrm{T}$ ) and in a $10 \mathrm{~g} / \mathrm{L}$ sodium sulfite solution (zero point calibration). After calibration the sensor is coupled with the agar disk and the biosensor is merged in a phosphate buffer ( $\mathrm{pH}=7.50 \pm 0.01$ ). Reached signal stability (fluctuation $\leq 0.01 \mathrm{ppm}$ within 15 minutes), the $\mathrm{O}_{2}$ concentration is ca. $7.00 \mathrm{ppm}\left(\mathrm{T}=25.0^{\circ} \mathrm{C} \pm 0.1\right.$ and $\left.\mathrm{P}_{\text {(barometric pressure) }}=760 \pm 5 \mathrm{mmHg}\right)$. The respiratory activity of the yeast cells under these conditions is due only to basal metabolism. The addition of the glucose solution (final concentration $0.5 \mathrm{~mol} / \mathrm{L}$ ) implies an increase in respiratory metabolism from the basal to the maximum level. The rate of cellular $\mathrm{O}_{2}$ consumption increases, dissolved $\mathrm{O}_{2}$ concentration, measured after the passage through the agar disk, decreases until a plateau (steady-state I, fluctuation $\leq 0.05 \mathrm{ppm}$ within 15 minutes). At steady-state I the rate of $\mathrm{O}_{2}$ diffusion inside the disk balances cellular $\mathrm{O}_{2}$ consumption.

At steady-state I, the chemical is added: if it exerts an inhibitory effect on cellular respiratory activity, the $\mathrm{O}_{2}$ consumption decreases and dissolved $\mathrm{O}_{2}$ concentration rises until the second plateau (steady-state II, fluctuation $\leq 0.05 \mathrm{ppm}$ within 15 minutes). To completely inhibit cellular respiration, $100 \mu \mathrm{L}$ of sodium azide $0.02 \mathrm{~mol} / \mathrm{L}$ is added. The signal increases to a third plateau (steady-state III, fluctuation $\leq 0.05 \mathrm{ppm}$ within 15 minutes).

The analytical parameter calculated from $\Delta \mathrm{ppm}\left(\mathrm{O}_{2}\right)_{\mathrm{I}-\mathrm{II}}$ and $\Delta \mathrm{ppm}\left(\mathrm{O}_{2}\right)_{\mathrm{I}-\mathrm{III}}$ (Figure 1) is a percentage index expressed as Inhibition of Respiratory Activity (IRA) [8]:

$$
\text { IRA index }=\left[\Delta \mathrm{ppm}\left(\mathrm{O}_{2}\right)_{\text {I-II }} / \Delta \mathrm{ppm}\left(\mathrm{O}_{2}\right)_{\text {I-III }}\right] \times 100
$$

The chemicals were tested each at 3 concentrations (ranging $0.20-0.42 \%(v / v)$ ). All experiments were performed in quadruplicate and the arithmetic means were calculated; repeatability was expressed as relative standard deviation (RSD \%).

\subsubsection{Improvements in Sensitivity: Lysis of the Cellular Wall}

For the cellular wall lysis, yeast cells were treated with the lytic enzyme zymolyase. It is a complex enzyme that 
posses $\beta-1,3$ glucanase and $\beta$-1,3-glucan laminaripentao-hydrolase activity, which hydrolyze glucose polymers at the $\beta$-1,3-glucan linkages releasing laminaripentaose as the principal product. Zymolyase also has alkaline protease activity. Cells were left in incubation (Petri dish) with the enzyme solution for 2 hours at room temperature $\left(25.0 \pm 0.1^{\circ} \mathrm{C}\right)$. Incubation conditions have been selected by testing different incubation times, and choosing the one striking both quality result and measurement time. The proper concentration of enzyme was selected depending on the number of cells in the disk.

The incubation solution was prepared by a solution of sorbitol $0.5 \mathrm{~mol} / \mathrm{L}$ with phosphate buffer $0.06 \mathrm{~mol} / \mathrm{L}$ at $\mathrm{pH}=7.50$, and $0.5 \mathrm{mg}$ of Zymolyase. Sorbitol was used as compatible solute, in such concentration to avoid lysis of the cell plasma membrane, due to the different osmotic pressure between internal and external of cells. After the fixed time the disks are washed with same solution of sorbitol $0.5 \mathrm{~mol} / \mathrm{L}$ in buffer. This wash was necessary to remove the enzyme and its possible interference with the measurement.

Respect to the methodology already established $[1,2,5,9,10]$ other variations have been introduced:

1) Using the serial dilution plate technique, cells counting was performed on Petri dishes with culture media of different composition (Table 1). The composition allowing obtaining a number of cells suitable for respirometric test was selected. Under substrate excess working conditions, the excessive number of cells would excessively lower residual dissolved $\mathrm{O}_{2}$ concentration at steady-state I; this condition would not allow a correct interpretation of the results and calculation of the IRA index.

2) Formaldehyde has been replaced by sodium azide as $100 \%$ respiration inhibitor. Comparative respirometric tests were performed by adding at the steady-state I formaldehyde $37 \%(13 \mathrm{~mol} / \mathrm{L})$ or different aliquots of sodium azide $0.02 \mathrm{~mol} / \mathrm{L}$ until increase to steady-state III. The variation of the dissolved $\mathrm{O}_{2}\left(\Delta \mathrm{ppm} \mathrm{O}_{2}\right)$ between the two steady-states was calculated and results are summarized in Table 2. Results obtained from comparative respirometric tests show that $\Delta \mathrm{ppm} \mathrm{O}_{2}$ obtained by adding already $50 \mu \mathrm{L}$ of sodium azide $0.02 \mathrm{~mol} / \mathrm{L}$ are comparable to those obtained by addition of $500 \mu \mathrm{L}$ of formaldehyde $13 \mathrm{~mol} / \mathrm{L}$. Therefore, sodium azide can replace formaldehyde (volatile chemical classified as carcinogen) [11] as respiration inhibitor in respirometric tests, with the advantage of handling less amount of a safer substance.

\section{Results and Discussion}

The biosensor based on intact yeast cells was exposed to SDS, $\mathrm{Hg}^{2+}$ and 4-CP (Table 3). For all the substances, IRA index increases in dose dependent fashion.

The higher values of IRA index were found for $\mathrm{Hg}^{2+}$ followed by SDS and 4-CP.

The biosensor based on intact yeast cells was also exposed to wood preservatives formulations (Table 4). The higher value of IRA index (97\%) found for CX-10 at $4.7 \%(\mathrm{v} / \mathrm{v})$ compared to same concentration of the others is explained by its known efficient kill of certain microorganisms, including S. cerevisiae [12].

For ACQ, CCA-C, and Tanalith $\mathrm{E}$ at the lowest concentration $(0.25 \%(\mathrm{v} / \mathrm{v}))$ the IRA index was undetectable, probably because at this concentration these substances are unable to pass the cell wall and act on mitochondrial function. The reason may be still valid for Tanalith $\mathrm{E}$ at $2.4 \%(\mathrm{v} / \mathrm{v})$ and therefore for this substance we tested a concentration point more.

The same methodology, exposure of modified yeast cells, was applied to a selection of chemicals: $\mathrm{Hg}^{2+}$ as more reactive agent on the system, and CCA-C. The only procedural change was the incubation time of disks (2 hours) with Zymolyase before assembling the biosensor. Results (Table 5) shows how the lysis of the cellular wall 1) increases the IRA index at all concentrations of all substances tested, up to 33\%; 2) allows detection at lower concentrations. In particular, the result of CCA-C at $0.25 \%(\mathrm{v} / \mathrm{v})$ is significant. The RSD\% (from 4 replicate analyses) ranged 3 to $7 \%$.

The metal cations (e.g. $\mathrm{Hg}^{2+}$ ) deserve some separate reflections. S. cerevisiae is capable of non-selective accumulation mechanism of cations; both intact yeast cells and/or isolated cell wall components show such chelation based cations retention [13]. Cell wall is structured as a $\beta 1,6$ and $\beta 1,3$ glucans chains network (55\% - 65\%) closely associated with chitin (1\% - 2\%), and mannoproteins (35\% - 40\%) [14]. All these cell wall components possess several binding sites (e.g. carboxyl, hydroxyl, amino, or imidazole groups) that could facilitate physicchemical interactions between the cell wall and the cations $[15,16]$ and could therefore slow down the intra-cellular passage. The second step of yeast uptake of metal cations involves the transport across the cell membrane through different transport mechanisms (e.g. diffusion or active transport) [17]. Probably in consequence of the partial wall removal, the diffusion of the cations within the cell is not hampered, thus leading 
Table 1. Cells counting by serial dilution plate technique; a: Traditional, b: Alternative; RSD $\% \leq 3$ on 4 replicates..

\begin{tabular}{cc}
\hline Culture medium composition & CFU/mL (106) \\
\hline a) yeast extract, $1 \%$; peptone, $1 \%$, glucose, $2 \%$ & 50.28 \\
b) yeast extract, $0.17 \%$; peptone, $0.17 \%$, glucose, $0.30 \%$ & 9.77 \\
\hline
\end{tabular}

Table 2. Comparison of respiration inhibitors; RSD\% $\leq 10$ on 4 replicates.

\begin{tabular}{ccc}
\hline Chemical & Aliquot $(\mu \mathrm{L})$ & $\Delta \mathrm{ppm}\left(\mathrm{O}_{2}\right)$ \\
\hline Formaldehyde $(13 \mathrm{~mol} / \mathrm{L})$ & 500 & 5.78 \\
& 50 & 5.82 \\
Sodium Azide $(0.02 \mathrm{~mol} / \mathrm{L})$ & 100 & 5.82 \\
& 200 & 5.86 \\
\end{tabular}

Table 3. IRA index $\%$; RSD $\% \leq 6$ on 4 replicates.

\begin{tabular}{cccc}
\hline & \multicolumn{2}{c}{ IRA index $\%$} \\
\hline Chemical & & Concentration (\%(v/v)) & \\
\cline { 2 - 4 } & 0.20 & 0.30 & 92 \\
\hline Hg(NO3)2 & 53 & 67 & 49 \\
SDS & 28 & 31 & 32 \\
4-CP & 20 & 26 & 92 \\
\hline
\end{tabular}

Table 4. IRA index $\%$; RSD $\% \leq 7$ on 4 replicates; ud = undetectable: nd = not determined.

\begin{tabular}{|c|c|c|c|c|}
\hline \multicolumn{5}{|c|}{ IRA index \% } \\
\hline \multirow{2}{*}{ Chemical } & \multicolumn{4}{|c|}{ Concentration $(\%(\mathrm{v} / \mathrm{v}))$} \\
\hline & 0.25 & 2.4 & 4.7 & 9.0 \\
\hline (Wolmanit) CX-10 & 88 & 93 & 97 & nd \\
\hline ACQ & ud & 22 & 79 & nd \\
\hline CCA-C (Tanalith C) & ud & 63 & 66 & nd \\
\hline Tanalith E & ud & ud & 42 & 93 \\
\hline
\end{tabular}

Table 5. Comparison of different biomediators: IRA index \% obtained with intact and modified yeast cells; ud = undetectable; $\mathrm{RSD} \% \leq 7$ on 4 replicates.

\begin{tabular}{|c|c|c|c|}
\hline Chemical & Concentration & IRA index \% Intact cells & IRA index \% Modified cells \\
\hline \multirow{3}{*}{ CCA-C } & $2.4 \%(\mathrm{v} / \mathrm{v})$ & 63 & 84 \\
\hline & $1.5 \%(\mathrm{v} / \mathrm{v})$ & 61 & 80 \\
\hline & $0.25 \%(\mathrm{v} / \mathrm{v})$ & ud & 34 \\
\hline \multirow{3}{*}{$\mathrm{Hg}$} & $0.42 \%(\mathrm{v} / \mathrm{v})$ & 92 & 98 \\
\hline & $0.30 \%(\mathrm{v} / \mathrm{v})$ & 67 & 81 \\
\hline & $0.20 \%(\mathrm{v} / \mathrm{v})$ & 53 & 69 \\
\hline
\end{tabular}

to the higher sensitivity of the modified yeast cells.

\section{Conclusions}

Aerobic respiration of $S$. cerevisiae is a rapid and useful toxicological endpoint. The simple treatment of the immobilized yeast cells disk with Zymolyase allows preparation of a more sensitive biomediator, still maintaining acceptable rapidity of the test.

The proposed methodology's improvement allows gaining in sensitivity, but the use of intact yeast cells allows working with solutions with different osmolarity (from distilled water to glucose 1M) without cell death due to lyses of cell plasma membrane. The proper design of the biosensor depends on the intended application. 


\section{Acknowledgements}

The work has been carried out in the frame of activities of the ALERT project (www.alert2015.it) funded by the Italian Ministry of economical development under the Call Industria 2015 "New technologies for Made in Italy".

\section{References}

[1] Campanella, L., Favero, G. and Tomassetti, M. (1995) Immobilised Yeast Cells Biosensor for Total Toxicity Testing. The Science of the Total Environment, 171, 227-234. http://dx.doi.org/10.1016/0048-9697(95)04673-0

[2] Haubenstricker, M.E., Meier, P.G., Mancy, K.H. and Brabec, M.J. (1990) Rapid Toxicity Testing Based on Yeast Respiratory Activity. Bulletin of Environmental Contamination and Toxicology, 44, 669-674. http://dx.doi.org/10.1007/BF01701786

[3] Campanella, L, Favero, G., Mastrofini, D. and Tomassetti, M. (1997) Further Developments in Toxicity Cell Biosensors. Sensors and Actuators B, 44, 279-286. http://dx.doi.org/10.1016/S0925-4005(97)00219-0

[4] Dragone, R. and Grasso, G. (2012) Biosensoristic Devices: Monitoring and Diagnostics in Agro-Zootechnical Productions. http://www.iss.it/binary/publ/cont/12_49_web.pdf

[5] Frazzoli, C., Dragone, R., Mantovani A., Massimi, C. and Campanella, L. (2007) Functional Toxicity and Tolerance Patterns of Bioavailable Pd(II), Pt(II), and Rh(III) on Suspended Saccharomyces cerevisiae Cells Assayed in Tandem by a Respirometric Biosensor. Analytical and Bioanalytical Chemistry, 389, 2185-2194. http://dx.doi.org/10.1007/s00216-007-1623-2

[6] Necas, O. (1971) Cell Wall Synthesis in Yeast Protoplasts. Bacteriological Reviews, 35, 149.

[7] Skaalure, S.C., Oppegard, S.C. and Eddington, D.T. (2008) Characterization of Sterilization Techniques on a Microfuidic oxygen delivery device. Journal of Undergraduate Researcher, 2, 1-5.

[8] Campanella, L., Dragone, R. and Favero, G. (2000) Method to Determine the Toxicity Caused by Exposure to Chemical and Physical Agents. Patent PCT Int Appl WO 00/75361 A2.

[9] Dragone, R., Frazzoli, C., Grappelli, C. and Campanella, L. (2009) A New Respirometric end Point-Based Biosensor to Assess the Relative Toxicity of Chemicals on Immobilized Human Cells. Ecotoxicology and Environmental Safety, 72 , 273-279. http://dx.doi.org/10.1016/j.ecoenv.2008.02.011

[10] Taccari, M., Comitini, F. and Casucci, C. (2011) Toxicity Assessment of Compounds in Soil Using a Simple Respirometric Technique. International Biodeterioration and Biodegradation, 65, 60-64. http://dx.doi.org/10.1016/j.ibiod.2010.02.008

[11] International Agency for Research on Cancer (2004) IARC Classifies Formaldehyde as Carcinogenic to Humans. http://www.iarc.fr/en/media-centre/pr/2004/pr153.html

[12] Huff, J., Qureshi, S., Hodgkinson, D., Nicklin, C., Göttsche, R., Hettler, W. and Roper, D.V. (2011) Microbiocidal Compositions and Their Use. US Patent No. 7,910,569.

[13] Wang, J. and Chen, C. (2006) Biosorption of Heavy Metals by Saccharomyces cerevisiae: A Review. Biotechnology advances, 24, 427-451. http://dx.doi.org/10.1016/j.biotechadv.2006.03.001

[14] Klis, F.M., Mol, P., Hellingwerf, K. and Brul, S. (2002) Dynamics of Cell Wall Structure in Saccharomyces cerevisiae. FEMS Microbiology Reviews, 26, 239-256. http://dx.doi.org/10.1111/j.1574-6976.2002.tb00613.x

[15] Jianlong, W. (2002) Biosorption of Copper (II) by Chemically Modified Biomass of Saccharomyces cerevisiae. Process Biochemistry, 37, 847-850. http://dx.doi.org/10.1016/S0032-9592(01)00284-9

[16] Brady, D., Stoll, A., D. Starke, L. and Duncan, J. R. (1994) Chemical and Enzymatic Extraction of Heavy Metal Binding Polymers from Isolated Cell Walls of Saccharomyces cerevisiae. Biotechnology and Bioengineering, 44, 297-302. http://dx.doi.org/10.1002/bit.260440307

[17] Pócsi, I. (2011) Toxic Metal/Metalloid Tolerance in Fungi-A Biotechnology-Oriented Approach. In: Bánfalvi, G., Ed., Cellular Effects of Heavy Metals, Springer Science+Business Media, 31-58. http://dx.doi.org/10.1007/978-94-007-0428-2__2 